\title{
Efficacy and Safety of Mistletoe Preparations (Viscum album) for Patients with Cancer Diseases
}

\author{
A Systematic Review
}

\author{
Jörg Melzer Felix Iten Katarina Hostanska Reinhard Saller \\ Institute of Complementary Medicine, Department of Internal Medicine, University Hospital Zurich, Switzerland
}

\author{
Key Words \\ Mistletoe - Viscum album . Complementary and alternative \\ medicine - Oncology - Systematic review - Anthroposophic \\ medicine $\cdot$ Phytotherapy $\cdot$ Supportive
}

\section{Summary}

Background: Mistletoe is often used as a complementary approach in oncology. Despite experimental anti-tumour effects and several reviews there remains controversy about its clinical role. Patients and Methods: Potentially relevant trials were identified to perform a systematic review (databases: e.g. EMBASE, MEDLINE; hand search: e.g. bibliographies; search terms: e.g. mistletoe). To be included, randomised or comparative clinical trials at least had to examine mistletoe preparations standardized according to manufacturing process and to describe interventions explicitly. Additionally, cohort studies were included for reasons of external validity. Results were summarised in tables. Results: 18 clinical trials $(>6,800$ participants) were included. Their internal quality was mostly low. Due to heterogeneity between trials a meta-analysis was impossible. Regarding efficacy, findings were inconsistent regarding life expectancy, relation to tumour entity, dosing and treatment duration. Yet, studies indicate that quality of life ( $\mathrm{OoL})$ is improved. As these findings do not seem to be limited to one of the different parenteral mistletoe preparations reviewed the treatment may be summarised under the umbrella term 'mistletoe therapy'. Regarding safety, 1 serious adverse event (AE) related to mistletoe was described; non-serious AEs were local reactions at injection site. Allergic reactions were rare. Conclusion: Supportive 'mistletoe therapy' seems safe and beneficial for $\mathrm{QoL}$ in adult patients with solid tumours. But there is an urgent need to confirm its efficacy in patient-centred care in a complex oncological setting. This has to be evaluated systematically in prospective observational trials with validated, multidimensional patient-rated QoL questionnaires and comparisons of different preparations and dosages.

\author{
Schlüsselwörter \\ Mistel · Viscum album · Komplementärmedizin · Onkologie · \\ Anthroposophische Medizin · Phytotherapie - Systematisches \\ Review · Supportiv
}

\section{Zusammenfassung}

Hintergrund: Mistelzubereitungen werden oft als komplementärmedizinischer Ansatz in der Onkologie eingesetzt. Trotz experimenteller Anti-Tumoreffekte und einigen Reviews ist ihr klinischer Stellenwert umstritten. Methode: Potenziell relevante Studien wurden ausgewählt, um ein systematisches Review zu erstellen (Datenbanken: z.B. EMBASE, MEDLINE; Handsuche: z.B. Bibliographien; Suchbegriffe: z.B. Mistel). Um eingeschlossen zu werden, mussten die randomisierten oder vergleichenden Studien Mistelzubereitungen untersuchen, die zumindest auf den Herstellungsprozess standardisiert waren und die Intervention genau beschrieben. Zusätzlich wurden Kohortenstudien zwecks externer Validität eingeschlossen. Die Ergebnisse wurden in Tabellen zusammengefasst. Ergebnisse: 18 klinische Studien ( $>6800$ Teilnehmer) wurden eingeschlossen. Ihre Qualität war meist niedrig. Aufgrund der Heterogenität der Studien war keine Metaanalyse möglich. Hinsichtlich Wirksamkeit waren die Ergebnisse uneinheitlich in Bezug auf Lebenserwartung, Tumorentität, Dosierung und Behandlungsdauer. Jedoch ergab sich aus den Studien ein Hinweis auf die Verbesserung der Lebensqualität $(\mathrm{Q} o \mathrm{~L})$. Da diese Resultate nicht auf eine der verschiedenen parenteralen Mistelzubereitung begrenzt zu sein scheinen, können die Interventionen unter dem Sammelbegriff "Misteltherapie» zusammengefasst werden. Hinsichtlich Sicherheit wurde 1 schwerwiegendes unerwünschtes Ereignis (UE) mit Bezug zur Mistelbehandlung berichtet, nicht schwerwiegende UE waren lokale Reaktionen an der Injektionsstelle. Allergische Reaktionen waren selten. Schlussfolgerung: Die supportive "Misteltherapie» scheint sicher und die Lebensqualität erwachsener Patienten mit soliden Tumoren zu verbessern. Jedoch gibt es dringenden Forschungsbedarf, um die Wirksamkeit im Rahmen eines patientenzentrierten komplexen onkologischen Settings zu evaluieren. Dies sollte systematisch in prospektiven Anwendungsbeobachtungen, mit verschiedenen Dosierungen und Behandlungsdauern, anhand validierter, multidimensionaler, von Patienten ausgefüllten Fragebögen zur Lebensqualität evaluiert werden.

\begin{tabular}{ll}
\hline KARGER & @ 2009 S. Karger GmbH, Freiburg \\
Fax +497614520714 & $\begin{array}{l}\text { Accessible online at: } \\
\text { www.karger.com/fok } \\
\text { Information@Karger.de }\end{array}$ \\
www.karger.com &
\end{tabular}




\section{Introduction}

There is a long tradition of using a variety of preparations made from European mistletoe (Viscum album L.) as folk remedies (e.g. its oral and topical use in ancient Greek and Celtic medicine) [1]. However, modern parenteral use of mistletoe extracts for patients with cancer was initiated in the 1920s by Rudolf Steiner (1861-1925) in the context of anthroposophic medicine $[2,3]$. On the basis of humanistic considerations, Steiner saw analogies between the aetiology and course of cancer on the one hand and growth principles of mistletoe on the other hand. Steiner developed anthroposophic medicine together with the physician Ita Wegman (1876-1943). Wegman herself made the first mistletoe preparation ('Iscar'), a precursor of today's Iscador brand preparations and used it starting in 1917 in cancer patients in Zurich. In keeping with the anthroposophic view of disease and medicinal doctrine, a sort of immune modulating action was postulated as the active principle, plus both direct and indirect inhibitory effects on tumour growth. In the following decades, other companies developed different mistletoe preparations. Therefore, mistletoe preparations from the field of anthroposophic medicine and from the field of phytotherapy are available today (table 1).

A considerable percentage of patients with cancer include treatments from complementary and alternative medicine (CAM) in their therapeutic approach along with oncological therapies. Respective surveys indicate a prevalence of 14.8 $91 \%$ for the use of CAM [4-8]. Yet, considering such a broad range, one should bear in mind that most of the surveys are not representative (e.g. different definitions of CAM, various survey methods as well as socio-cultural contexts, economic status and health care systems) $[6,9,10]$. Nevertheless, in
German-speaking countries (Austria, Germany, Switzerland) parenteral mistletoe preparations traditionally are one of the most commonly used CAM treatments of patients with cancer diseases along with their standard oncological treatment [4, 5 ] and non-representative data suggest a prevalence of its use between $29-77 \%$ [4, 8, 11]. Yet, differences between countries have to be considered (patients' use: e.g. $0 \%$ reported in hospitals in Turkey [12] or Japan [13], but $96 \%$ in an anthroposophic hospital in Switzerland [14]).

In order to bridge the gap between traditional use and current research evidence of mistletoe preparations we thought it was necessary to systematically review efficacy and safety of mistletoe preparations in clinical trials, to give a short overview on the possible mechanisms of action and to outline clinically useful prerequisites for future research while taking into account the patients' perspective.

\section{Aspects of Mistletoe, Its Preparations and Treatment}

Mistletoe, Viscum album [L.], is a plant with a partially woody stem that, as a semi-parasite, lives epiphytically on the branches of a variety of deciduous and coniferous trees. The herbal drug used is defined as the stems and leaves. From this raw material various commercially available preparations are made (e.g. pressed sap or extract). Mistletoe extracts are complex herbal preparations (i.e. multi-compound), contain various biologically active substances, and their content may vary depending on harvest time, species of the host tree and manufacturing process [16-18]: e.g. mistletoe lectins (ML), viscotoxins, amino acids, flavonoids, phenylpropanoids, triterpenes, phytosterol, alkaloids, polyalcohols, polysaccharides. The different fractions

Table 1. Different mistletoe preparations used in the clinical trials reviewed (given in various dosages)

\begin{tabular}{|c|c|c|c|c|c|}
\hline Preparation & Extract & Host tree & Application & $\begin{array}{l}\text { Dosage } \\
\text { (mg extract or ng ML) }\end{array}$ & Standardisation \\
\hline \multicolumn{6}{|c|}{ Phytotherapeutic preparations } \\
\hline Eurixor $^{\circledR}$ & aqueous (herb) & poplar & $\begin{array}{l}\text { subcutaneous, } \\
\text { s.c. (i.c., i.v.) }\end{array}$ & $1 \mathrm{mg}$ or $70 \mathrm{ng} /$ ampule $(1 \mathrm{ml})$ & (ML-I) \\
\hline Lektinol $^{\circledR}$ & aqueous (herb) & poplar & s.c. (i.v.) & $\begin{array}{l}0.02-0.07 \mathrm{mg} \text { or } 15 \mathrm{ng} / \mathrm{ampule} \\
(0.5 \mathrm{ml})\end{array}$ & ML-I \\
\hline \multicolumn{6}{|c|}{ Anthroposophic preparations } \\
\hline Helixor $^{\circledR}$ & aqueous (herb) & $\begin{array}{l}\text { apple (M: Malus), } \\
\text { fir (A:. Abies), } \\
\text { pine (P: Pinus) }\end{array}$ & s.c. & $\begin{array}{l}0.01-50 \mathrm{mg} / \mathrm{amp} .(1 \mathrm{ml}) \\
100 \mathrm{mg}(2 \mathrm{ml})\end{array}$ & process \\
\hline Iscador $^{\circledR}$ & $\begin{array}{l}\text { aqueous lacto-fermented } \\
\text { (herb) }\end{array}$ & $\begin{array}{l}\text { M, P, A, } \\
\text { elm (U: Ulmus), } \\
\text { oak (Q: Quercus) }\end{array}$ & s.c. & $\begin{array}{l}0.0001-20 \mathrm{mg} \\
\text { / ampule }(1 \mathrm{ml})\end{array}$ & process \\
\hline Isorel $^{\circledR}$ & aqueous (planta tota) & $\mathrm{M}, \mathrm{P}, \mathrm{A}$ & s.c.; i.m. & $1-60 \mathrm{mg}$ & process \\
\hline
\end{tabular}

*E.g. no clinical trials with Iscador M specified 1-5 mg extract (50-250 ng ML) with a lectin content defined as total lectin content analysed by ELISA-Test with ML II as standard. 
and components exhibit varying activity profiles, especially in regard to cytotoxic, anti-neoplastic, and immunomodulatory effects which seem to be dose-dependent.[19]

To ensure that the quality of each extract as a whole is as consistent as possible, mistletoe preparations today undergo a standardized manufacturing process ('process standardized'). Yet, some newer preparations have been standardized to certain components as well (e.g. to ML; table 1). Standardisation means to adjust a drug powder or extract to a specified norm value indicating a minimum and maximum content, of a substance or substance group that is considered to determine its efficacy. Mistletoe preparations, no matter if standardized to ML or to the manufacturing process are available in differing dosages. To date, no generally accepted treatment scheme is available for mistletoe preparations but subcutaneous injections of the different preparations twice a week are found frequently. Yet, empirically, older anthroposophic preparations are often administered at dosages that change rapidly, some according to a rhythmic sequence or in so called treatment series. In contrast, phytotherapeutic and newer anthroposophic preparations standardized to ML are usually administered at the same dosage over a longer treatment period before any adjustments are made.

\section{Aspects of Preclinical Research}

From the large number of constituents in mistletoe extracts (table 1) those best described with pharmacological activities are lectins, viscotoxins, and polysaccharides.

Mistletoe Lectins: Lectins are glycoproteins of non-immune origin that bind carbohydrates reversibly and do not exhibit antibody functions. Intense investigations of mistletoe extracts have led to the isolation of three major MLs: ML-I binds preferentially to $\beta$-galactosides, ML-II to $\beta$-galactosides and $\mathrm{N}$-acetylgalactosamins, whereas ML-III recognizes $\mathrm{N}$-acetylgalactosamins [22]. MLs are the most investigated single component of mistletoe extracts. The cytotoxicity of different mistletoe extracts and MLs is well documented in numerous cultivated cancer cell lines, as is their immunomodulating response [19, 23-25, 33]. The cytotoxic effects of the mistletoe extracts on tumour cells are not only due to the ribosome-inactivating properties, but also depend on the direct induction of apoptosis [39-41]. Interestingly, induction of apoptosis by ML or extracts in cancer cells was found in concentrations of low cytotoxicity. However, the cytotoxicity and apoptosis-inducing activity of mistletoe extracts seem strongly lectin-related [19, 40, 43].

As to immunomodulatory effects, the influence of different mistletoe extracts and MLs on the cells of the natural (innate) and of the specific immune system have been described in cultured cell lines, animals and humans. NK cells deserve special attention because they have been described as the target cells of mistletoe extract [19]. ML enhanced the cytotoxicity of NK cells in vitro [24] as well as the activation of macrophages. The animal models indicate that the immunomodulatory potency of mistletoe extracts and/or lectins is involved in the anti-tumour and anti-metastatic effect [45]. It can be assumed that lectin is the essential compound regarding the immunological activity of mistletoe extracts. However, its effect could be modulated by other components. A very important property of mistletoe extracts and MLs is their ability to stimulate cytokine production in immunocompetent cells [19, $25,46]$. In comparative studies with extracts standardized to ML and isolated lectins, the extent of cytokine release was higher with mistletoe extracts than with isolated lectin [46]. Recently, treatment with lectin in combination with ionising radiation resulted in an additive anti-proliferative effect on p53-deficient murine tumour cells and also on radiation-resistant human adenocarcinoma SW480 cells [42]. In addition, the combination of ML and different chemotherapeutic drugs caused an additive and/or synergistic effect on the cytotoxicity towards lung cancer cells [47]. These results reflect that the combination of mistletoe therapy with chemotherapy and/or radiotherapy gives hope for new clinical perspectives.

Viscotoxins: Viscotoxins are basic polypeptides related to a group of thionins [26]. They have a low molecular weight of about $5 \mathrm{kDa}$. In contrast to the numerous studies on the cytotoxicity of ML only few studies have investigated the toxicity of viscotoxins, but induced cell death much faster by damaging the cell membrane, leading to necrosis [44]. On human lymphocytes viscotoxins exerted rapid membrane-permeabilizing effects accompanied by the generation of reactive oxygen intermediates, which led to necrotic cell death [27]. Apart from the cytotoxic effects of viscotoxins, enhancement of phagocytosis and oxidative bursting of human granulocytes were described [28], as well as increased natural killer (NK) cell-mediated toxicity [29].

Oligo- and Polysaccharides: Amongst the compounds with high molecular weights, most probably the polysaccharides are the active components [30]. Rhamnogalacturonan samples from commercially available extracts of mistletoe grown on different host trees (apple tree, oak, pine) demonstrated a dose-dependent enhancement of cytotoxicity to NK, lymphocyte activated killer (LAK) and activated $\mathrm{CD}^{+} \mathrm{T}$ cells.

The most prominent properties of mistletoe extracts are their immunomodulatory $[19,31]$ and cytotoxic effects [23] in cultured cells and animals studies. Studies with the isolated components of mistletoe extracts are useful in understanding the molecular mechanisms underlying the beneficial effect of the therapeutic preparation, however they do not take into account the positive or negative additive effect of different components in the final preparation, e.g. with polysaccharides and viscotoxins [23, 32]. Recently, new peer-reviewed articles have been published, representing the most updated collection of translational mistletoe research [34-38].

In addition, the protective effect of mistletoe extracts should be mentioned: they improved DNA repair of lym- 
phocytes in breast cancer patients [48] and prevented activation marker depression on $\mathrm{T}$ cells mediated by cyclophosphamid [49]. However, single substances (i.e. ML, viscotoxin) did not prevent this depression.

\section{Aspects of Clinical Research}

In 1989, Kiene published the first comprehensive review of the available very heterogeneous prospective and retrospective, controlled and uncontrolled clinical trials on mistletoe, and revised it in 1996 [50, 51]. The authors considered only one third of the studies as meaningful, not least because of considerable weaknesses in methodology and data presentation. They evaluated the results as being indications of relevant efficacy and therapeutic superiority when mistletoe preparations were included in the treatment of patients with cancerous tumours. In 1994, Kleijnen and Knipschild [52] published another systematic review. The authors considered only 11 of the studies to be methodologically sound, and therefore, relevant. However, since the methodological quality of the studies was on the whole unsatisfactory, the authors considered the data as insufficient to give evidence for anti-neoplastic efficacy. In 2003, Ernst and colleagues [53] published a systematic review which included only 10 randomised controlled trials (RCTs) and emphasized the methodological deficiencies of most of the studies. Yet, they stated that the methodologically weaker studies indicated that the use of mistletoe provides some benefit with respect to quality of life (QoL), whereas the methodologically more sound studies (defined by quality score [54]) did not confirm this. Also in 2003, Kiene and Kienle published a comprehensive systematic review $[2,55]$ in which they not only included RCTs, but also all prospective clinical trials they found (23). A complicated 4-level quality score comprising 11 items was used. This assessment demonstrated beneficial effects in terms of survival ( 8 studies), overall QoL $(n=3)$, and reduction of side-effects of the oncological therapy $(\mathrm{n}=3)$, yet 1 study indicated a negative trend for disease-free survival and in 4 no effect on survival. The generally positive assessment of the study quality clearly contradicts the result of Ernst et al. [53]. In 2007, the systematic review of Kienle et al. on 25 trials with anthroposophic mistletoe preparations reports - while stating the known quality limitations - a benefit on survival in 5 of 10 RCTs but points out that the best evidence of efficacy of mistletoe therapy remains for the improvement of QoL (3 of 5 RCTs) and the reduction of sideeffects of cytotoxic therapies (e.g. chemotherapy, radiation: 3 of 5 RCTs, 2 non-RCTs). The latest systematic review of Horneber et al. [56] drew basically similar conclusions on the improvement of QoL due to additional mistletoe therapy.

This list of reviews on mistletoe shows, that up to date the various authors - despite of their different in- and exclusion criteria or rating parameters - come to a similar result concerning a possible benefit on QoL. But the academic discussion is continued without taking into account the patients' needs and giving constructive arguments for future research. Moreover, Ernst's sceptical estimation of the benefit of mistletoe therapy was intensified in a fiercely discussed editorial, where he characterized mistletoe therapy as ineffective according to current publications [57]. However, since the above mentioned systematic reviews were completed new clinical trials have been published $[58,59]$. Therefore, this paper gives an updated review. Above all, it aims to serve cancer patients by taking into account what they value most in face of the available clinical evidence and a rational for the mode of action.

\section{Materials and Methods}

Potentially relevant clinical trials were searched in the following databases (1968 - February 2007): AMED, BIOETHICSLINE, BIOSIS, CATLINE, CISCOM, Cochrane Complementary Medicine (field registry of randomised clinical trials and controlled clinical trials), EMBASE, INT. HEALTH TECHNOLOGY, MEDLINE. The search terms used were: abnoba, cancer, clinical trial, Eurixor, Helixor, Iscador, Iscucin, Isorel, Lektinol, malignancy, mistletoe, mistletoe lectins, Plenosol, Viscum, Vysorel. As inclusion criterion the respective publications had to evaluate at least process standardized mistletoe preparations either in randomised or comparative controlled trials or cohort studies (due to external validity) in systemic interventions, e.g. subcutaneous (and/or per infusion) in patients with cancer.

In addition, the reference lists of all relevant articles and the following journals (which are currently not, or only partially, listed in databases) were hand searched: Erfahrungsheilkunde, Therapeutikon (discontinued), Ärztezeitschrift für Naturheilverfahren, Schweizerische Zeitschrift für Ganzheitsmedizin. The languages were limited to German, French and English.

Studies that investigated intravenous injection, intravesicular or intrapleural application of mistletoe preparations were excluded, as were studies with insufficient or incomprehensible explanations of study condition, patient number, or survey instrument. Incomplete information about dosage (mostly in older studies) was no reason for exclusion because the dosage of mistletoe can change repeatedly over the course of treatment and constant dosing therefore is not commonly practiced. Publications of abstracts or phase I and II studies were not included. If published more than once, the publication with the more detailed description or complete publication of the results or the publication from a peer-reviewed journal was selected. The use of MLs as a single substance was also excluded because such preparations are investigational drugs and have not been approved for use as medicinal products. Data extraction and validation were performed by two authors and checked by a third author using standardized, predefined criteria: study design, sample size, patient description, interventions, primary endpoints and main results. The Jadad Score (internal validity, i.e. randomisation, blinding) was not used to evaluate methodological quality [54] because we included trials with external validity (e.g. observational) as well, and so it would not have been a general quality score. The decision to include observational studies was based on the fact that problems with recruiting patients for randomised trials on mistletoe have repeatedly been reported [60-62]. Hence, observational trials which have been performed in the last years, give at least some additional information close to daily medical practice. Additionally, one could question the possible blinding of trials on mistletoe because patients might know from various sources that injecting mistletoe extracts can cause local reactions. As a matter of fact, it has been published that the majority of study participants were able to correctly identify whether 
they had received mistletoe or placebo [61] and local side-effects are common [75]. Moreover, awareness of randomisation can controvert greatly a patient's intention for a specific therapy. Many patients deliberately choose mistletoe as part of their cancer treatment. Explicitly choosing a therapy that contradicts a patient's own subjective vision [63] can be a significant factor regarding efficacy, which seems specifically associated with the use of mistletoe and cannot be casually transferred to comparable therapies or placebo treatments. Therefore, requiremen for randomisation can deter a considerable percentage of patients intending to use mistletoe treatment from participating in a study [60,61]. This relativises the principle of randomisation as a criterion of quality in the context of mistletoe treatment. Nevertheless, table 2 (c.f. www.karger. com/doi/10.1159/000226249) enables a reproducible, multidimensional assessment of quality without using a formal rating score but still shows the various weaknesses and potential strengths of each trial due to the detailed information. However, we listed the trials according to the different mistletoe preparations to see if the evidence prevails for one or another.

\section{Results}

19 publications of 18 different trials (approximately 6,800 participants) published in German or English met the inclusion criteria (table 2; 1 study [64] was included even though the authors classified it as phase II because it contained a reference group).

Study Design: The quality of the randomised and observational trials varied but was often low. Additionally, across the studies, interventions and outcome parameters varied considerably. Therefore, the heterogeneity of the trials or insufficient data presentation still makes a meta-analysis impossible. Interestingly, an overview of the clinical trials indicates a change in outcome parameters over the decades: Until the late 1980s, research primarily focused on survival time and incidence and/or duration of remissions. Not until the 1990s, aspects of QoL were included in the studies [65-68]. From 2000 onwards, research seems to concentrate on QoL (table 2).

Study Outcome: The abovementioned change in clinical research might be related to the results one can carefully extract from the studies: The data are inconclusive about whether life expectancy is increased. Yet, regarding QoL several studies indicate an improvement (e.g. improved physical and psychological wellbeing). The present findings give ground for the assumption that the evidence of the role of mistletoe therapy in a complex oncological setting might be that of a supportive treatment, which was the situation in all the reviewed studies. Yet, some studies with high internal validity did not show such a benefit. However, as mistletoe therapy can stimulate the cellular part of the immune system (e.g. NK cells, macrophages) this could partly explain physical improvements which can contribute to an improvement of QoL in patients with cancer along with current oncological therapy. Nevertheless, QoL was measured by various instruments in the trials (one- and multidimensional questionnaires, mostly patientrated but also questioning by third parties [59, 69-73]; table 3 ) and apart from physiological improvements, other dimensions contributing to QoL, like psychological ones, have not yet been examined systematically (e.g. patients' autonomy, theory of self-regulation).

Additionally, some trials state that mistletoe therapy improves patients' tolerability of chemotherapy and radiotherapy. This is discussed by others as well [74] but has to be confirmed in future trials.

The treatment duration of mistletoe therapy ranged from weeks to years as it might have depended on the respective treatment situation. In practice and in the course of time, a therapy sometimes becomes a form of secondary or tertiary prophylaxis against metastases and recurrence. However, treatment duration and postulated aspects of prophylaxis have not been sufficiently tested in the clinical trials.

Mistletoe Preparations: In all the studies reviewed, 5 different mistletoe preparations either standardized to process or MLs were used (table 1). In German-speaking European countries some of these preparations are registered by health authorities as drugs and reimbursed by general health insurance (e.g. in Switzerland different preparations of Iscador and Helixor). So far, the possible benefit on QoL does not seem to be limited to a specific mistletoe preparation, although some pharmacological effects might give ground for the administration of extracts standardized to ML. But at present, for some mistletoe preparations standardized to ML (e.g. Iscador spec.) no clinical trials are available. Therefore, to aid a comprehensive clinical assessment of the current state of evidence, it seems justified to use the term 'mistletoe therapy' as an umbrella term for the use of the different mistletoe preparations. Mistletoe therapy can be defined as the therapeutic use of the parenteral medicinal products made from mistletoe which are reviewed in this paper. Using this term gives some kind of a rational to search for an overall outcome parameter that can be used to describe or to postulate an efficacy common to the different preparations and treatment plans used in the trials. This can help to find the role of this treatment for patients in an oncological setting.

Cancer Entity: The different mistletoe preparations were studied in a variety of solid cancer diseases such as: often breast and colorectal, but also glioma, abdominal, pancreatic, bladder, ovarian, cervical, bronchial/lung cancer, head/neck carcinoma, and malignant melanoma. The possible benefit on QoL does not seem to be linked to a specific tumour entity which might give ground for the role of mistletoe as a supportive treatment improving QoL in a complex oncological setting.

Safety: In terms of safety, the available studies indicate that mistletoe therapy is well tolerated although a systematic evaluation is lacking in some trials. Serious adverse events (AEs) definitely related to mistletoe therapy were not reported except for 1 patient with angiooedema [71]. AEs related to mistletoe therapy were: (a) local (at the injection site): e.g. pruritus, erythema, induration; (b) systemic: e.g. flu-like syndrome, fatigue, fever, and headache. The data about the incidence of AEs ranges widely. Especially in mistletoe therapy it is a 
Table 3. QoL instruments used in the clinical trials reviewed [76-81]

\begin{tabular}{|c|c|c|}
\hline Instrument & Design & $\begin{array}{l}\text { User / time necessary / } \\
\text { rating / since }\end{array}$ \\
\hline \multicolumn{3}{|c|}{ Multidimensional questionnaires rated by patients } \\
\hline EORTC QLQ-C-30 & $\begin{array}{l}6 \text { areas (func., phys., soc., psych., global, therapy) } \\
30 \text { questions, } 1-4 \text { points }\end{array}$ & $\begin{array}{l}\text { adults } / 5-15 \mathrm{~min} / \\
\downarrow \text { points }=\uparrow \text { QoL } / 1993\end{array}$ \\
\hline $\begin{array}{l}\text { Functional Assessment } \\
\text { of Cancer Therapy - General } \\
\text { (FACT-G) }\end{array}$ & $\begin{array}{l}5 \text { areas (phys., soc., emo., func., relationship with } \\
\text { physician) } \\
28 \text { questions (last } 7 \text { days), } 0-4 \text { points }\end{array}$ & $\begin{array}{l}\text { adults } / 5-10 \mathrm{~min} / \\
\uparrow \text { points }=\uparrow \text { QoL/1987-1992 }\end{array}$ \\
\hline $\begin{array}{l}\text { Functional Living Index: Cancer } \\
\text { (FLIC) }\end{array}$ & $\begin{array}{l}25 \text { areas (phys., func., soc., psych., therapy) } \\
2 \text { questions, LAS }\end{array}$ & $\begin{array}{l}\text { adults } /<10 \mathrm{~min} / \\
\uparrow \mathrm{LAS}=\uparrow \text { QoL } / 1984\end{array}$ \\
\hline Global Life Quality (GLQ-8) & $\begin{array}{l}2 \text { areas (phys., emo.) } \\
8 \text { questions, LAS }\end{array}$ & $\begin{array}{l}\text { adults / 3-5 min / } \\
\uparrow \mathrm{LAS}=\downarrow \text { QoL / } 1990 \text { / during chemotherapy }\end{array}$ \\
\hline $\begin{array}{l}\text { Medical Outcome Study (MOS) 36-Item } \\
\text { Short Form (SF-36) / SF-12 }\end{array}$ & $\begin{array}{l}8 \text { areas (phys. function/limitation, soc., pain, mental, } \\
\text { emo., vitality, perception) } \\
36 \text { questions, } 1-6 \text { points }\end{array}$ & $\begin{array}{l}\text { from age } 14 / 15 \mathrm{~min} / \\
\uparrow \text { points }=\downarrow \text { QoL } / 1992\end{array}$ \\
\hline \multicolumn{3}{|c|}{ Multidimensional questionnaires rated by third party } \\
\hline $\begin{array}{l}\text { Spitzer Quality of Life Index } \\
\text { (QLI) }\end{array}$ & $\begin{array}{l}5 \text { areas (activity, daily living, health, support/soc., } \\
\text { outlook/emo.) } \\
5 \text { questions, } 0-2 \text { points }\end{array}$ & $\begin{array}{l}\text { adults } / 5 \min / \\
\uparrow \text { points }=\uparrow \text { QoL } / 1981\end{array}$ \\
\hline \multicolumn{3}{|c|}{ One-dimensional questionnaire rated by third party } \\
\hline $\begin{array}{l}\text { Karnofsky Performance Status Scale } \\
\text { (KPS) }\end{array}$ & 1 question (func. $0-100 \%$ ) & $\begin{array}{l}\text { adults / } 2 \text { min / } \\
\uparrow \%=\uparrow \text { QoL / } 1949 \\
\text { does not comply with today's definition of QoL }\end{array}$ \\
\hline Spitzer Quality of Life Uniscale & $\begin{array}{l}\text { Cumulative (phys., mental, emo.) } \\
1 \text { question } \\
\text { Visual Analogue Scale (VAS) }\end{array}$ & $\begin{array}{l}\text { adults } / 1 \min / \\
\uparrow \mathrm{VAS}=\uparrow \mathrm{QoL} / 1981\end{array}$ \\
\hline $\begin{array}{l}\text { Traditional Chinese Medicine Score } \\
\text { (TCM-score) }\end{array}$ & $\begin{array}{l}1 \text { area (phys.) } \\
5 \text { questions } \\
0-4 \text { points }\end{array}$ & $\begin{array}{l}-* /-* / \\
\downarrow \text { points }=\uparrow \text { QoL / -* }\end{array}$ \\
\hline \multicolumn{3}{|c|}{$\begin{array}{l}\text { emo }=\text { Emotional; func. }=\text { functional; LAS }=\text { linear analogue scale; } \text { phys. }=\text { physiological; } \text { psych. }=\text { psychological; soc. }=\text { social. } \\
*=\text { No published data about validation available and no response by authors. } \\
\uparrow=\text { High; } \downarrow=\text { low. }\end{array}$} \\
\hline
\end{tabular}

matter of ongoing debate whether some of the most common AEs, the local ones are considered or interpreted as undesired or actually desired (e.g. kind of surrogate for general physiological response). According to this, the data about the incidence of side effects ranges widely. Only a few of the studies reviewed here $[58,70]$ explicitly differentiate between local and systemic side-effects. The cumulated numbers are $17.5 \%$ for total side-effects, $15.9 \%$ for local, and $1.6 \%$ for systemic side-effects. These data are more or less comparable to the result of a previous systematic review on AEs under mistletoe therapy which showed local reactions between $0.9-43 \%$ and systemic reactions between $0.8-4 \%$ depending on the interpretation whether being desirable or undesirable [75]. Allergic reactions occurred but the frequency was approximately $<1 \%$. These results were confirmed by the data of authorities and manufacturers, as far as they were available [75].

\section{Discussion}

Clinical research on the use of mistletoe preparations in oncology has reached a complex state with the different systematic reviews (e.g. varying inclusion criteria, quality ratings, mistletoe preparations) which indicate an improvement of QoL. The present review of randomised and observational clinical trials of supportive 'mistletoe therapy' (as defined above) next to standard oncological treatments shows a possible benefit on patients' QoL, a reasonable safety profile but inconsistent data on survival or anti-tumour effects. One has to point out, that to date all these findings seem to be more or less independent of the tumour entity examined or the mistletoe preparation used, although other authors recently have postulated that the benefit might be specific to patients with breast tumours [56]. No definite conclusion can be drawn on dosing or treatment duration although clinical and pharmacological data support the use of low-dose ML-standardized mistletoe extracts over several months. 
One has to be aware, that the trials reviewed were performed under different prevailing regulations and hence diverging quality standards (e.g. International Committee on Harmonisation, Good Clinical Practice).

The shortcomings of the present review might be that no validated rating system was employed to measure study quality and that it was not limited to randomised trials. Yet, if one keeps in mind the problems involved in recruiting patients for randomised trials on mistletoe therapy and the questionability of successful blinding due to very common local reactions, it seems justified to include observational studies and consequently, to do without rating internal quality.

The strength of this review is that it lists the studies according to the different preparations. This enables the analysis that up to date the results are not triggered by a specific mistletoe preparation, and therefore, gives some ground to speak of 'mistletoe therapy'. Furthermore, by mapping the research evidence from the clinical trials reviewed with the given summary of main data concerning the mode of action and patients' values and adding our clinical experience, we try to bridge the gap between research and practice which sometimes occurs due to a simplistic view of evidence-based medicine (EBM) although its promoters define EBM in a very complex way (i.e. research evidence, physician's expertise, patient's needs and values) $[82,83]$.

Aspects Due to the Mode of Action: A pharmacologically oriented view indicates that for immunomodulatory effects of mistletoe therapy relatively low dose preparations have to be used. Such effects have been observed in healthy volunteers as well, yet can be expected to be smaller under oncological treatment. However, to achieve anti-neoplastic (e.g. pro-apoptotic, cytotoxic) effects in clinical trials, much higher doses may be required. One would have to bear in mind, however, that due to cytotoxic effects of higher concentrations (e.g. eventually from regular single doses of $50 \mathrm{ng}$ ML twice weekly upwards) side-effects (e.g. lymphocytopenia) might have to be expected as well, which could finally contradict QoL (e.g. immunosuppressive effects). Therefore, haematological controls (e.g. neutrophil subpopulations) are indicated under mistletoe therapy.

Patient Values and Aspects in Regard to QoL: Next to the pharmacologically explainable immunomodulatory effects and consequently possible physical improvements (e.g. increased appetite, better sleep, less fatigue, lower susceptibility to respiratory infections), one needs to consider psychological effects which can contribute to the efficacy of mistletoe therapy. In surveys among oncological patients, those using CAM (i.e. predominantly mistletoe therapy) stated a less overall deterioration of their health status than non-users, and CAM use was associated with better coping with their disease [8]. Other surveys have stated that patients' motivations of CAM use are e.g. maintenance of autonomy, a conscious use of resources, especially a support of the immune system/resistance or generally a personal contribution to therapy or reduction of side-effects [5]. These data show the importance of patientcentred criteria especially in supportive CAM treatments and the present review supports this approach. In practice, a closer look on terms such as 'resistance' shows, that in a patient's perspective, these are by no means limited to the 'immune system' but include multidimensional (i.e. 'holistic') aspects. 'Resistance' appears to be a complex metaphor for numerous processes and ideas meaningful to a patient in securing his individual existence. Besides a more or less specific impact on the immune system to fight cancer and infections, other aspects play an important role, e.g. to overcome physical and psychological weakness, anxiety, doubt, powerlessness. Treatment with mistletoe preparations might offer both 'biochemical' and individually definable assistance in coping with cancer. Mistletoe therapy, carefully chosen by both patient and physician could help considerably to initiate or increase autonomy in dealing with the disease. Various lines of thoughts and conceptions in CAM / anthroposophic medicine may play a decisive role.

During the course of their disease, many patients have to decide whether to start mistletoe therapy based on their own considerations or on the advice of others. Of course, this may be related to expectations that are based on the patients' mental and emotional attitudes towards life, their cancer disease and to some degree also on their knowledge and awareness of experimental research. Empirical reports from other patients and their relatives also play a large role. Including the patients' ideas (e.g. on how to deal with the tumour, and associated threats and limitations, how to contribute to recovery and probably healing) is one general factor affecting efficacy. The subjective selection of mistletoe therapy may be relevant to the treatment. Also, patients may take over a very active role in their treatment by administering the individual dose s.c. themselves. This type of therapy can contribute greatly, beyond palliative and supportive effects, to individual resource allocation (e.g. mobilisation of hope and strength). On a functional level, the concept of activating individual resources (e.g. immunomodulation) focuses on a treatment attempt that activates parts of the body, in this case an at least partially operational - and therefore influenceable - immune system. This approach enables patients to perceive themselves not only as someone who suffers from cancer (e.g. disease as a deficit), but as individuals that therapeutically activate organs of their body. Self-administering of such a supportive therapy with definable biological effects and consequently, a physical efficacy which fits into a patient's range of treatment strategies, might contribute to strengthen his or her autonomy. It remains to be examined how such feedback loops of physical and psychological effects can be made operational.

Patients' Safety, Interactions: Additionally to the abovementioned results on AEs it seems necessary to point out that pharmacological studies on possible interactions with mistletoe therapy are widely lacking [84]. If in terms of QoL its main efficacy is in the area of immunomodulatory effects (cellular 
immunity) - next to psychological effects - an interaction with phase II enzymes seems unlikely, but nevertheless would have to be examined. Up to date only one interim report of a phase I study with the concomitant use of Gemcitabine/Helixor in 16 patients (mamma, pancreas, colorectal cancer) concerning pharmacokinetics, dose-limiting toxicity and $\mathrm{AE}$ is available and no significant changes (e.g. area under the curve, plasma concentration) have been found [85]. Pharmacokinetic trials examining possible interactions with other chemotherapies as well as hormone or immune therapy would be useful to be able to increase patients' safety.

Despite the large number of preclinical research data on anti-neoplastic effects (e.g. cytotoxic, anti-tumour), the results of one working group about the possibility to experimentally stimulate the growth of tumour cells with mistletoe or individual mistletoe substances were stressed repeatedly (e.g. tumour proliferation in isolated cell lines and increased pulmonary metastatic formation in an animal model, each with isolated MLs at a low dosage range). But these results could not be reproduced by other groups, neither with isolated MLs nor with whole extracts; and in some of the reproduced experiments, comparable doses even resulted in inhibited tumour growth [86-88]. Yet, regardless of experimental trials, we consider mistletoe therapy a contraindication at least in patients with acute leukaemia (lack of clinical trials) due to immunomodulatory effects (e.g. possible stimulation of leukocytes).

Future Research: Under the premises that mistletoe therapy can have a benefit on QoL it seems worthwhile to consider to leave former research focuses (e.g. survival, anti-tumour effects) aside and to optimise research on aspects of QoL (e.g. physiological and psychological wellbeing). The current gold standard in EBM, the RCT, does not include studies based on patient-centred criteria. Furthermore, some criteria of internal quality (i.e. randomisation, blinding) aim to exclude fundamentally subjective factors that probably affect mistletoe therapy (e.g. patient's preference, psychological, mental, spiritual viewpoints). Therefore, a modern evaluation would have to make use of study types and outcome instruments that address research questions according to mistletoe therapy as a patient-centred supportive treatment. Although to date, a generally accepted definition of QoL does not exist, the following may give a hint on the different aspects that may contribute to a patient's QoL: 'QoL is the satisfaction of an individual with his or her physical, emotional, spiritual, social' and, one might add, psychological situation [89]. In the face of such a complex, yet realistic definition, only multidimensional, patient-rated, disease-specific, and validated questionnaires seem suitable to evaluate the benefit of mistletoe therapy on QoL in prospective observational trials. Questions specific to the use of mistletoe could be added. To acquire a better knowledge about dosing mistletoe preparations standardized to $\mathrm{ML}$ or to the manufacturing process solely should also be studied in different concentrations, because the clinical research evidence to date does not support the administration of high concentrations. Connected with dosing is the question of the duration of the treatment which would probably have to be examined in the range from months up to 1 year starting with or during standard oncological treatment. It would probably be useful to analyse certain research questions like immunomodulatory and cytotoxic effects of low and high dosages in healthy volunteers first, in order to corroborate these data and to develop further strategies for patients.

\section{Conclusion}

According to the available evidence in the field of mistletoe therapy, the present review gives some ground for an approach in order to serve the patient: Under the aim of a supportive therapy main concerns of cancer patients can be respected, if clinical research evidence is combined with a rational for the mode of action, the clinical expertise of the physician in charge of the therapy, and by integrating patients' values. In general, mistletoe therapy is not an 'alternative' to oncological therapies (e.g. operation, chemo- or radiotherapy). But it seems safe and beneficial for the improvement of QoL in patients with solid tumours. However, there is a lack of research to consolidate its supportive efficacy as a patientcentred care in a complex oncological setting. This has to be studied at least in prospective observational trials (using different dosages, preparations, time intervals) and evaluated with validated, multidimensional patient-rated QoL instruments.

\section{Online Supplemental Material}

Table 2. Summary of clinical trials with mistletoe therapy - listed according to different preparations (www.karger.com/doi/10.1159/000226249)

\section{Acknowledgment}

This work was in part funded by an unconditional grant from WELEDA, Switzerland.

\section{Conflict of Interest}

None declared. The Institute of Complementary Medicine (ICM) was responsible for the conduct of the project on the following bases: (1) the protocol design and literature searches were the responsibility of the ICM; (2) all data management and analyses were conducted by the ICM; (3) interpretation of results was the prerogative of our institution; and (4) publication of results was to occur regardless of the outcome of the review. 


\section{References}

1 Müller-Jahncke W-D, Friedrich C: Geschichte der Pharmazie. Band 2. Eschborn, Govi, 2005.

2 Kienle G, Kiene H: Die Mistel in der Onkologie. Stuttgart, Schattauer, 2003.

$>3$ Kienle GS, Kiene H: Complementary cancer therapy: a systematic review of prospective clinical trials on anthroposophic mistletoe extracts. Eur J Med Res 2007:12:103-19.

4 van der Weg F, Streuli RA: Use of alternative medicine by patients with cancer in a rural area of Switzerland. Swiss Med Wkly 2003;133:233-40.

5 Nicolaisen-Murmann K, Thiel F, Mohrmann S, Grünewald E, Ackermann S, Bender H, Beckmann $\mathrm{M}$, Fasching P: Complementary and alternative medicine in women with gynecological and breast malignancies - a multicenter study exploring prevalence and motivation. Geburtsh Frauenheilkd 2005; 65:178-185.

6 Molassiotis A, Fernadez-Ortega P, Pud D, Ozden G, Scott JA, Panteli V, Margulies A, Browall M, Magri M, Selvekerova S, Madsen E, Milovics L, Bruyns I, Gudmundsdottir G, Hummerston S, Ahmad AM, Platin N, Kearney N, Patiraki E: Use of complementary and alternative medicine in cancer patients: a European survey. Ann Oncol 2005;16:655-63.

7 Yates JS, Mustian KM, Morrow GR, Gillies LJ, Padmanaban D, Atkins JN, Issell B, Kirshner JJ, Colman LK: Prevalence of complementary and alternative medicine use in cancer patients during treatment. Support Care Cancer 2005;13:806-11.

8 Fasching PA, Thiel F, Nicolaisen-Murmann K, Rauh C, Engel J, Lux MP, Beckmann MW, Bani MR: Association of complementary methods with quality of life and life satisfaction in patients with gynecologic and breast malignancies. Support Care Cancer 2007; 15:1277-84.

9 Andrews GJ, Wiles J, Miller KL: The geography of complementary medicine: perspectives and prospects. Complement Ther Nurs Midwifery 2004;10: 175-85.

10 Schraub S: Unproven methods in cancer: a worldwide problem. Support Care Cancer 2000;8:10-5.

11 Schonekaes K, Micke O, Mucke R, Buntzel J, Glatzel M, Bruns F, Kisters K: [Use of complementary/alternative therapy methods by patients with breast cancer]. Forsch Komplementarmed Klass Naturheilkd 2003;10:304-8

12 Yildirim Y, Tinar S, Yorgun S, Toz E, Kaya B, Sonmez S, Balsak D:The use of complementary and alternative medicine (CAM) therapies by Turkish women with gynecological cancer. Eur J Gynaecol Oncol 2006; 27:81-5.

13 Yoshimura K, Ichioka K, Terada N, Terai A, Arai Y Use of complementary and alternative medicine by patients with localized prostate carcinoma: study at a single institute in Japan. Int J Clin Oncol 2003; 8:26-30.

14 Heusser P, Braun SB, Ziegler R, Bertschy M, Helwig $S$, van Wegberg B, Cerny T: Palliative in-patient cancer treatment in an anthroposophic hospital: I. Treatment patterns and compliance with anthroposophic medicine. Forsch Komplementmed 2006;13: 94-100.

15 Munstedt K, von Georgi R: [Unconventional cancer therapies - comparisons of attitudes and knowledge between physicians in Germany and Greece] Forsch Komplementarmed Klass Naturheilkd 2005; 12:254-60.

16 Hajto T, Hostanska K, Saller R: [Mistletoe therapy from the pharmacologic perspective]. Forsch Komplementarmed 1999;6:186-94.
17 Becker H, Scheer J: Kurzer Überblick über die Inhaltsstoffe der Mistel; in Schilcher H (ed): Fortschritte in der Misteltherapie. Aktueller Stand der Forschung und klinische Anwendung. Essen, KVC, 2005, pp 3-11.

18 Mansky PJ: Mistletoe and cancer: controversies and perspectives. Semin Oncol 2002;29:589-94.

19 Hajto T, Hostanska K, Berki T, Palinkas L, Boldizsar F, Nemeth P: Oncopharmacological perspectives of a plant lectin (Viscum album agglutinin-I): overview of recent results from in vitro experiments and in vivo animal models, and their possible relevance for clinical applications. Evid Based Complement Alternat Med 2005;2:59-67.

20 Arzneimittel-Kompendium der Schweiz 2008. www. kompendium.ch [accessed: 03.11.08].

21 Rote Liste Online 2008. www.rote-liste.de [accessed: 03.11.08]

22 Franz H, Ziska P, Kindt A: Isolation and properties of three lectins from mistletoe (Viscum album L.). Biochem J 1981;195:481-4.

23 Zarkovic N, Trbojevic-Cepe M, Ilic Z, Hrzenjak M, Grainca S, Jurin M: Comparison of the effects of high and low concentrations of the separated Viscum album L. lectins and of the plain mistletoe plant preparation (Isorel) on the growth of normal and tumor cells in vitro. Period boil 1995;97:61-67.

24 Hajto T, Hostanska K, Weber K, Zinke H, Fischer J, Mengs U, Lentzen H, Saller R: Effect of a recombinant lectin, Viscum album agglutinin on the secretion of interleukin-12 in cultured human peripheral blood mononuclear cells and on NK-cell-mediated cytotoxicity of rat splenocytes in vitro and in vivo. Nat Immun 1998;16:34-46.

25 Stein GM, Pfuller U, Schietzel M, Bussing A: Expression of interleukin-4 in apoptotic cells: stimulation of the type-2 cytokine by different toxins in human peripheral blood mononuclear and tumor cells. Cytometry 2000;41:261-70.

26 Coulon A, Mosbah A, Lopez A, Sautereau AM, Schaller G, Urech K, Rouge P, Darbon H: Comparative membrane interaction study of viscotoxins A3, A2 and B from mistletoe (Viscum album) and connections with their structures. Biochem J 2003; 374:71-8.

27 Büssing A, Rosenberger A, Stumpf C, Schietzel M: [Development of lymphocyte subsets in tumor patients after subcutaneous administration of mistletoe extracts]. Forsch Komplementarmed 1999;6: 196-204.

28 Stein GM, Schaller G, Pfuller U, Wagner M, Wagner B, Schietzel M, Bussing A: Characterisation of granulocyte stimulation by thionins from European mistletoe and from wheat. Biochim Biophys Acta 1999; 1426:80-90.

29 Tabiasco J, Pont F, Fournie JJ, Vercellone A: Mistletoe viscotoxins increase natural killer cell-mediated cytotoxicity. Eur J Biochem 2002;269:2591-600.

30 Edlund U, Hensel A, Frose D, Pfuller U, Scheffler A: Polysaccharides from fresh Viscum album L. berry extract and their interaction with Viscum album agglutinin I. Arzneimittelforschung 2000;50:645-51.

31 Hajto T: Immunomodulatory effects of Iscador: a Viscum album preparation. Oncology 1986;43(suppl 1): 51-65.

32 Knopfl-Sidler F, Viviani A, Rist L, Hensel A: Human cancer cells exhibit in vitro individual receptiveness towards different mistletoe extracts. Pharmazie 2005; 60:448-54.
3 Boneberg EM, Hartung T: Mistletoe lectin-1 increases tumor necrosis factor-alpha release in lipopolysaccharide-stimulated whole blood via inhibition of interleukin-10 production. J Pharmacol Exp Ther 2001;298:996-1000.

34 Kelter G, Fiebig HH: Absence of tumor growth stimulation in a panel of 26 human tumor cell lines by mistletoe (Viscum album L.) extracts Iscador in vitro. Arzneimittelforschung 2006;56:435-40.

35 Elluru S, Van Huyen JP, Delignat S, Prost F, Bayry J, Kazatchkine MD, Kaveri SV: Molecular mechanisms underlying the immunomodulatory effects of mistletoe (Viscum album L.) extracts Iscador. Arzneimittelforschung 2006;56:461-6.

36 Mossalayi MD, Alkharrat A, Malvy D: Nitric oxide involvement in the anti-tumor effect of mistletoe (Viscum album L.) extracts Iscador on human macrophages. Arzneimittelforschung 2006;56:457-60.

37 Harmsma M, Ummelen M, Dignef W, Tusenius KJ, Ramaekers FC: Effects of mistletoe (Viscum album L.) extracts Iscador on cell cycle and survival of tumor cells. Arzneimittelforschung 2006;56:474-82.

38 Eggenschwiler J, Patrignani A, Wagner U, Rehrauer H, Schlapbach R, Rist L, Ramos MH, Viviani A: Gene expression profiles of different breast cancer cells compared with their responsiveness to fermented mistletoe (Viscum album L.) extracts Iscador from oak (Quercus), pine (Pinus), white fir (Abies) and apple tree (Malus) in vitro. Arzneimittelforschung 2006;56:483-96.

39 Bussing A, Suzart K, Bergmann J, Pfuller U, Schietzel $\mathrm{M}$, Schweizer K: Induction of apoptosis in human lymphocytes treated with Viscum album L. is mediated by the mistletoe lectins. Cancer Lett 1996;99: 59-72.

40 Duong van Huyen JP, Delignat S, Kazatchkine MD, Kaveri SV: Comparative Study of the sensitivity of lymphoblastoid and transformed monocytic cell lines to the cytotoxic effects of Viscum album extracts of different origin. Chemotherapy 2003; 49:298-302.

41 Harmsma M, Gromme M, Ummelen M, Dignef W, Tusenius KJ, Ramaekers FC: Differential effects of Viscum album extract IscadorQu on cell cycle progression and apoptosis in cancer cells. Int J Oncol 2004;25:1521-9.

42 Hostanska K, Vuong V, Rocha S, Soengas MS, Glanzmann C, Saller R, Bodis S, Pruschy M: Recombinant mistletoe lectin induces p53-independent apoptosis in tumour cells and cooperates with ionising radiation. Br J Cancer 2003;88:1785-92.

43 Bussing A, Schietzel M: Apoptosis-inducing properties of Viscum album L. extracts from different host trees, correlate with their content of toxic mistletoe lectins. Anticancer Res 1999;19:23-8.

44 Bussing A, Vervecken W, Wagner M, Wagner B, Pfuller U, Schietzel M: Expression of mitochondrial Apo2.7 molecules and caspase-3 activation in human lymphocytes treated with the ribosome-inhibiting mistletoe lectins and the cell membrane permeabilizing viscotoxins. Cytometry 1999;37:133-9.

45 Van Huyen JP, Delignat S, Bayry J, Kazatchkine MD, Bruneval P, Nicoletti A, Kaveri SV: Interleukin-12 is associated with the in vivo anti-tumor effect of mistletoe extracts in B16 mouse melanoma. Cancer Lett 2006;243:32-7.

46 Elsasser-Beile U, Voss M, Schuhle R, Wetterauer U: Biological effects of natural and recombinant mistletoe lectin and an aqueous mistletoe extract on human monocytes and lymphocytes in vitro. J Clin Lab Anal 2000;14:255-9. 
47 Siegle I, Fritz P, McClellan M, Gutzeit S, Murdter TE: Combined cytotoxic action of Viscum album agglutinin-1 and anticancer agents against human A549 lung cancer cells. Anticancer Res 2001;21: 2687-91.

48 Kovacs E, Hajto T, Hostanska K: Improvement of DNA repair in lymphocytes of breast cancer patients treated with Viscum album extract (Iscador). Eur J Cancer 1991;27:1672-6.

49 Büssing A, Regnery A, Schweizer K: Effects of Viscum album L. on cyclophosphamid-treated peripheral blood mononuclear cells in vitro: Sister chromatoid exchanges and activation/proliferation marker expression. Cancer Lett 1995;94:199-205.

50 Kiene H: Klinische Studien zur Misteltherapie karzinomatöser Erkrankungen. Eine Übersicht. Therapeutikon 1989;3:347-353.

51 Kiene H: Beurteilung klinischer Studien zur Misteltherapie; in Berg P (ed): Grundlagen der Misteltherapie. Stuttgart, Hippokrates, 1996, pp 484-493.

52 Kleijnen J, Kniepschild P: Mistletoe treatment for cancer - review of controlled trials in humans. Phytomedicine 1994;1:255-260.

-53 Ernst E, Schmidt K, Steuer-Vogt MK: Mistletoe for cancer? A systematic review of randomised clinical trials. Int J Cancer 2003;107:262-7.

54 Jadad AR, Moore RA, Carroll D, Jenkinson C, Reynolds DJ, Gavaghan DJ, McQuay HJ: Assessing the quality of reports of randomized clinical trials: is blinding necessary? Control Clin Trials 1996;17:1-12.

55 Kienle GS, Berrino F, Bussing A, Portalupi E Rosenzweig S, Kiene H: Mistletoe in cancer - a systematic review on controlled clinical trials. Eur J Med Res 2003;8:109-19.

56 Horneber MA, Bueschel G, Huber R, Linde K, Rostock M: Mistletoe therapy in oncology. Cochrane Database Syst Rev 2008:CD003297.

57 Ernst E: Mistletoe as a treatment for cancer. BMJ 2006;333:1282-3.

58 Augustin M, Bock PR, Hanisch J, Karasmann M, Schneider B: Safety and efficacy of the long-term adjuvant treatment of primary intermediate- to high-risk malignant melanoma (UICC/AJCC stage II and III) with a standardized fermented European mistletoe (Viscum album L.) extract. Results from a multicenter, comparative, epidemiological cohort study in Germany and Switzerland. Arzneimittelforschung 2005;55:38-49.

59 Semiglazov VF, Stepula VV, Dudov A, Schnitker J, Mengs U: Quality of life is improved in breast cancer patients by Standardised Mistletoe Extract PS76A2 during chemotherapy and follow-up: a randomised placebo-controlled, double-blind, multicentre clinical trial. Anticancer Res 2006;26:1519-29.

60 Gerhard I, Abel U, Loewe-Mesch A, Huppmann S, Kuehn JJ: [Problems of randomized studies in complementary medicine demonstrated in a study on mistletoe treatment of patients with breast cancer] Forsch Komplementarmed Klass Naturheilkd 2004, 11:150-7.

61 Rostock M, Huber R: Randomized and doubleblind studies - demands and reality as demonstrated by two examples of mistletoe research. Forsch Komplementarmed Klass Naturheilkd 2004; 11(suppl 1):18-22.

62 von Rohr E, Pampallona S, van Wegberg B, Hurny C, Bernhard J, Heusser P, Cerny T: Experiences in the realisation of a research project on anthroposophical medicine in patients with advanced cancer. Schweiz Med Wochenschr 2000;130:1173-84.
63 Hilsden RJ, Verhoef MJ: Complementary therapies: evaluating their effectiveness in cancer. Patient Educ Couns 1999;38:101-8.

64 Goebell PJ, Otto T, Suhr J, Rübben H: Evaluation of an unconventional treatment modality with mistletoe lectin to prevent recurrence of superficial bladder cancer: A randomized phase II trial. J Urol 2002; 168:72-75.

65 Dold U, Edler L, Mäurer HC, Müller-Wening D, Sakellariou B, Trendelenburg E, Wagner G: Krebszusatztherapie beim fortgeschrittenen nichtkleinzelligen Bronchialkarzinom. Stuttgart, Thieme, 1991.

66 Heiny B, Albrecht V, Beuth J: Lebensqualitätsstabilisierung durch Mistellektin-1 normierten Extrakt beim fortgeschrittenen kolorektalen Karzinom. Der Onkologe 1998;4(suppl 1):S35-S39.

67 Lenartz D, Stoffel B, Menzel J, Beuth J: Immunoprotective activity of the galactoside-specific lectin from mistletoe after tumor destructive therapy in glioma patients. Anticancer Res 1996;16:3799-802.

68 Grossarth-Maticek R, Kiene H, Baumgartner SM, Ziegler R: Use of Iscador, an extract of European mistletoe (Viscum album), in cancer treatment: prospective nonrandomized and randomized matchedpair studies nested within a cohort study. Altern Ther Health Med 2001;7:57-66, 68-72, 74-6 passim.

69 Semiglasov VF, Stepula VV, Dudov A, Lehmacher W, Mengs U: The standardised mistletoe extract PS76A2 improves QoL in patients with breast cancer receiving adjuvant CMF chemotherapy: a randomised, placebo-controlled, double-blind, multicentre clinical trial. Anticancer Res 2004;24:1293-302.

70 Bock PR, Friedel WE, Hanisch J, Karasmann M, Schneider B: [Efficacy and safety of long-term complementary treatment with standardized European mistletoe extract (Viscum album L.) in addition to the conventional adjuvant oncologic therapy in patients with primary non-metastasized mammary carcinoma. Results of a multi-center, comparative, epidemiological cohort study in Germany and Switzerland]. Arzneimittelforschung 2004;54:456-66.

71 Piao BK, Wang YX, Xie GR, Mansmann U, Matthes H, Beuth J, Lin HS: Impact of complementary mistletoe extract treatment on quality of life in breast, ovarian and non-small cell lung cancer patients. A prospective randomized controlled clinical trial. Anticancer Res 2004;24:303-9.

72 Schierholz J, Piao BK, Wang YX, Xie GR, Mansmann U, Matthes H, Beuth J, Lin HS: Komplementäre Tumortherapie mit standardisiertem Mistelgesamtextrakt. Ergebnisse einer kontrollierten prospektiven randomisierten klinischen Multicenterstudie. Dtsch Z Onkologie 2003;35:186-194.

73 Steuer-Vogt MK, Bonkowsky V, Ambrosch P, Scholz M, Neiss A, Strutz J, Hennig M, Lenarz T, Arnold W: The effect of an adjuvant mistletoe treatment programme in resected head and neck cancer patients: a randomised controlled clinical trial. Eur J Cancer 2001;37:23-31

74 Lange-Lindberg A: Misteltherapie als begleitende Behandlung zur Reduktion der Toxizität der Chemotherapie. Deutsches Institut für Medizinische Dokumentation und Information (DIMDI), 2006.
75 Saller R, Kramer S, Iten F, Melzer J: Unerwünschte Wirkungen der Misteltherapie bei Tumorpatienten - eine systematische Übersicht; in Scheer R, Bauer R, Becker H, Fintelmann V, Kemper F, Schilcher H (eds): Fortschritte in der Misteltherapie. Aktueller Stand der Forschung und klinische Anwendung. Essen, KVC, 2005, pp 367-403.

76 Aaronson N, Ahmedzai S, Bergmann B, et al: The European Organization for Research and Treatment of Cancer QLQ-C30: a quality-of-life instrument for use in international clinical trials in oncology. J Natl Cancer Inst 1993;85:365-376.

77 Cella DF, Tulsky DS, Gray G, Sarafian B, Linn E, Bonomi A, Silberman M, Yellen SB, Winicour P, Brannon J, et al: The Functional Assessment of Cancer Therapy Scale: development and validation of the general measure. J Clin Oncol 1993;11:570-9.

78 Cheung YB, Goh C, Wong LC, Ng GY, Lim WT, Leong SS, Tan EH, Khoo KS: Quick-FLIC: validation of a short questionnaire for assessing quality of life of cancer patients. Br J Cancer 2004;90:1747-52.

79 Coates A, Glasziou P, McNeil D: On the receiving end - III. Measurement of quality of life during cancer chemotherapy. Ann Oncol 1990;1:213-7.

80 Ware J, Sherbourne C: The Mos 36-Item Short-Form Health Survey (SF36). Med Care 1990;30:473-483.

81 Spitzer WO, Dobson AJ, Hall J, Chesterman E, Levi J, Shepherd R, Battista RN, Catchlove BR: Measuring the quality of life of cancer patients: a concise QL-index for use by physicians. J Chronic Dis 1981 34:585-97.

82 Sackett D, Strauss S, Richardson W, Rosenberg W, Haynes R: Evidence-Based Medicine. How to Practice and Teach EBM, ed 2. Edinburgh, Churchill Livingstone, 2000.

83 Straus SE, Sackett DL: Applying evidence to the individual patient. Ann Oncol 1999;10:29-32.

84 Mansky PJ, Grem J, Wallerstedt DB, Monahan BP, Blackman MR: Mistletoe and gemcitabine in patients with advanced cancer: a model for the phase I study of botanicals and botanical-drug interactions in cancer therapy. Integr Cancer Ther 2003; 2:345-52.

85 Mansky PJ, Wallerstedt DB, Monahan BP, Lee C, Swain S, Evande R, Blackman M, Grem J: Mistletoe extract/gemcitabine combination treatment an interim report from the NCCAM/NCI phase I study in patients with advanced solid tumors. J Clin Oncol 2005;23:S216.

86 Kelter G, Schierholz JM, Fischer IU, Fiebig HH: Cytotoxic activity and absence of tumor growth stimulation of standardized mistletoe extracts in human tumor models in vitro. Anticancer Res 2007; 27:223-33.

87 Burger AM, Mengs U, Kelter G, Schuler JB, Fiebig $\mathrm{HH}$ : No evidence of stimulation of human tumor cell proliferation by a standardized aqueous mistletoe extract in vitro. Anticancer Res 2003;23:3801-6.

88 Maier G, Fiebig HH: Absence of tumor growth stimulation in a panel of 16 human tumor cell lines by mistletoe extracts in vitro. Anticancer Drugs 2002;13:373-9.

89 Donnelly S, Rybicki L, Walsh D: Quality of life measurement in the palliative management of advanced cancer. Support Care Cancer 2001;9:361-5. 